\title{
High and low value fish chains in the Mekong Delta: challenges for livelihoods and governance
}

\author{
Vo Thi Thanh Loc $\cdot$ Simon R. Bush • Le Xuan Sinh • \\ Nguyen Tri Khiem
}

Received: 24 April 2009/Accepted: 5 January 2010/Published online: 29 January 2010

(C) The Author(s) 2010. This article is published with open access at Springerlink.com

\begin{abstract}
This paper investigates the structure, function and wealth distribution within the Pangasius hypophthalmus and Henicorhynchus spp./Labiobarbus spp. value chains in the Mekong Delta of Vietnam. The analysis is driven by key questions relating to the form and function of value chains, their contribution to the livelihoods of farmers and fishers, the effectiveness of government policy and the potential for value chain governance mechanisms, such as contracts and certification, to steer towards sustainable production. The results indicate that actors in the high value Pangasius hypopthalmus export chain have a higher potential income, but face considerably higher economic vulnerability from global markets. Alternatively, Henichorhychus/Labiobarbus spp. fishers are severely constrained in their ability to negotiate higher prices for their fish but appear to be less vulnerable to economic and environmental change. The paper concludes that for value chain governance to improve the livelihoods of fishers and farmers in both high and low value chains, new arrangements are needed that better accommodate customary institutions and informal market relations.
\end{abstract}

Keywords Mekong · Vietnam · Fisheries · Value chains · Governance · Sustainability

Readers should send their comments on this paper to BhaskarNath@aol.com within 3 months of publication of this issue.

V. T. T. Loc $(\bowtie) \cdot$ L. X. Sinh

Can Tho University, Can Tho, Vietnam

e-mail: vttloc@ctu.edu.vn

S. R. Bush

Wageningen University, Wageningen, The Netherlands

e-mail: simon.bush@wur.nl

N. T. Khiem

An Giang University, An Giang, Vietnam 


\section{Introduction}

The sustainable development of the fisheries sector in the Mekong Delta of Vietnam (Fig. 1) is dependent on a shared understanding of how fishery resources are exploited through both domestic and international value chains (Loc et al. 2007). Faced with the poor enforcement of 'internal' state legislation, the Vietnamese government has turned to 'external' value chain governance mechanisms (see Kaplinsky 2000; Humphrey and Schmitz 2004), including production contracts and certification, to improve efficiency and promote higher environmental performance and social equity. Given the dependency of rural populations on Mekong fisheries, both capture and culture (Sinh 2007), it is widely believed improved value chain governance will contribute to the more efficient transfer of

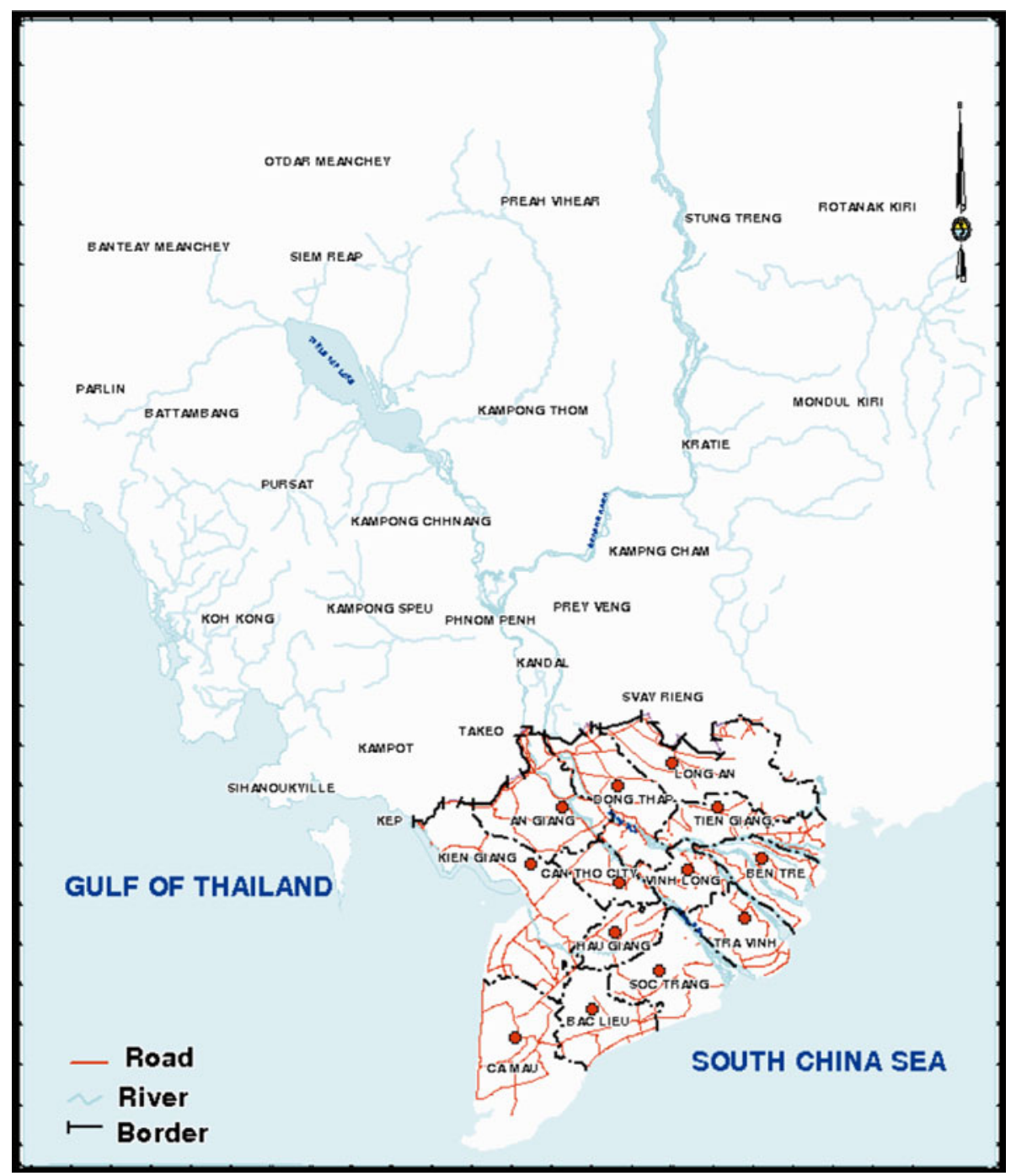

Fig. 1 Study provinces in the Mekong Basin 
fish to market, providing higher margins for fishers and farmers, and improved leverage for steering the industry towards sustainable production.

This paper addresses these assumptions by providing new insights into the domestic structure, function and wealth distribution within value chains for Pangasius hypophthalmus and Henicorhynchus spp./Labiobarbus spp. in the Mekong Delta. Pangasius hypophthalmus represents a high global chain, with approximately 650,000 tonnes of fillets traded to international markets at a value of US\$1.45 billion (Dung 2008). In contrast, Henicorhynchus spp. and Labiobarbus spp. (Ca Linh in Vietnamese) provides a staple supply of essential protein to fishers in all of the riparian countries, as well as being traded extensively in local and regional markets fresh, dried and fermented (Bush and Le Minh 2006).

The research combines value chain and livelihoods analysis (Kaplinsky and Morris 2000; Ellis 2000; Mitchell and Shepherd 2006) to address three main questions: (1) What are the key functions of chain actors in different market channels, where are they located and what proportion of total market value they receive? (2) What contribution does each value chain make to the livelihoods of fishers and farmers? (3) What are the challenges for implementing improved value chain governance? By unravelling the structure and function of these domestic chains, we focus our attention on the capacity of Henicorhynchus spp./ Labiobarbus spp. fishers and $P$. hypophthalmus farmers to maintain their livelihoods dependent on access to these value chains, and the potential of state and non-state governance arrangements to steer the industry towards more equitable and environmentally responsible production practices.

The paper begins with a description of the methodology used in the value chain and livelihoods analysis, followed by the presentation of results. The remainder of the paper discusses the form and function of the two value chains, the role of income generation and bargaining power, and finally, the potential of value chain governance mechanisms to steer more environmental friendly and more equitable production of both aquaculture and fisheries in the Mekong Delta.

\section{Methodology}

The data for this study were generated through a combined value chain and livelihoods analysis. The value chain analysis, based on the approach of Kaplinsky and Morris (2000) and Porter (1998, 2000), maps the material and financial flows from input suppliers to market. The methodology enabled us to calculate the main expenses and net profit margins of production for the actors and consolidate the expenses and margins from the rest of the chain. The analysis emphasises the value added to the fish at each transaction in the chain, calculated as the selling price minuses buying price, not taking into account fixed or variable costs of each actor. The data were then mapped using the ValueLinks approach developed by GTZ (2007), illustrating the main export and domestic channels, proportional outputs and a description of key functions.

The livelihoods survey focused on the contribution of the P. hypophthalmus and Henicorhynchus spp./Labiobarbus spp. value chains to household income and the degree to which both farmers and fishers are able to make decisions over productive activities and investment strategies (Ellis 2000; Mitchell and Shepherd 2006). As such, the analysis moved beyond 'household'-related factors to include a broader range of economic and political 'mediating processes' that govern production practices and access to markets (Allison and Ellis 2001). The livelihood analysis, therefore, provides a description of 
decision-making and investment strategies in light of power relations between market actors and rules that govern access to local, regional and international chains (Dorward et al. 2003). In addition, questions were asked about the current shift from state to marketbased governance approaches in Vietnam, more specifically focusing on farmers' and fishers' awareness of state and market-based regulation and their current level of compliance.

In total, 421 discrete chain actors were surveyed in September and October 2008, collecting information for their production for January-December 2007. Informants included were: 90 fish farmers, 91 fishing households, 10 Pangasius hatcheries, 7 processing companies, 22 traders and 20 chain facilitators (NGOs and government departments), across An Giang, Dong Thap and Hau Giang provinces. In addition, six focus group discussions were held to validate the results, and a large workshop was held at the end of the field research with a wide range of private sector companies and government departments, from both the national and provincial levels, to explore the policy implications of the findings. The three provinces are representative of fishery production in the Mekong Delta, together accounting for $74 \%$ of total area and $68 \%$ of the total production volume of Pangasius. Similarly, they account for $\sim 70 \%$ of the total catch of Henicorhynchus spp. and Labiobarbus spp. by volume (Thoa 2009). Two districts with the largest culture area and production volume were chosen from each province: Chau Thanh and Chau Phu (An Giang), Cao Lanh and Thanh Binh (Dong Thap), and Vinh Thanh and Thot Not (Hau Giang). Within these districts, two communes were randomly selected to take part in the survey.

\section{Pangasius hypopthalmus value chain}

\subsection{Volume, functions and channels}

The survey recorded 1.2 million tonnes of Pangasius traded in 2007 representing an estimated $28.9 \%$ of total aquaculture production in Vietnam and $50.6 \%$ in the Mekong Delta. Of this, $91.4 \%$ of the trade was exported, emphasising the international nature of the industry (Fig. 2). There are five distinct functions within the chains including a general group of input suppliers, grow-out and hatchery farmers, traders, processors and retailers. The composition of chains actors differed depending on whether the channel extended to domestic or export markets, but the function of these actors across the channels remained relatively similar.

The Pangasius chain is predominantly export oriented and, as a result, dominated by processing companies. The first channel in Vietnam is a vertically integrated international chain extending from producers to processors and export markets. The export trade extends to well-established markets such as Japan, United States and European Union, as well as emerging markets such as Egypt, Russia and Ukraine. The results indicate that nearly all producers selling fish to export markets have a direct contract with processing companies, thereby avoiding the extra costs incurred by collectors. This is not consistent with other studies that show that collectors play an important role in trading Pangasius and providing credit to farmers (Bush and Le Minh 2006; Loc 2006). Nevertheless, the results indicate that there is a tendency towards vertical integration by processing companies in order to maintain greater control over farming practices.

The second channel is a domestic flow of fish from producers, to traders, wholesalers and finally consumers in major urban centres such as Ho Chi Minh City. This channel 


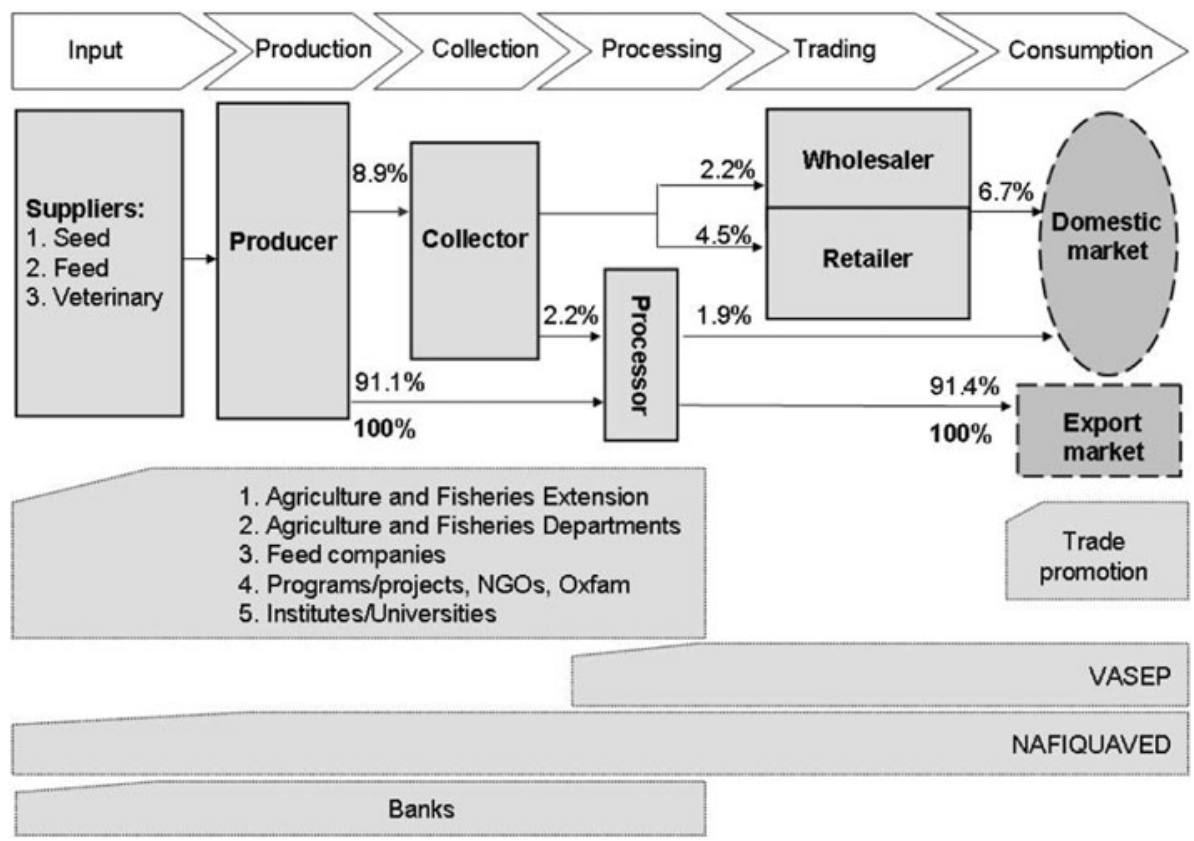

Fig. 2 Pangasius value chain in Vietnam

accounts for $8.9 \%$ of total production, passing from producers to collectors, who then sell to wholesalers, retailers or processing companies. Approximately, one-third of the fish sold in domestic markets is processed, made up of both filleted fish as well as waste material from processing companies. The domestic chain is also a secondary market for those farmers who do not meet the quality or safety requirements of export markets. Quality failures mainly consist of meat discolouration or fish that cannot be delivered live to processing companies, while safety failures mainly include problems with antibiotic or probiotic contamination. The survey results indicate that most disqualification from export markets occurs at the farm gate as only $1.9 \%$ of fish is traded from processing companies to domestic markets.

\subsection{Pangasius chain facilitators}

A large number of state, private and civil society organisations facilitate both domestic and international trade of Pangasius (Fig. 2). Market support is provided by the Vietnam Association of Seafood Exporters and Processors (VASEP) who provide processors and exporters information and training on quality and safety requirements. In addition, the Provincial Trade Promotion Center and the National Trade Promotion Center explore new export markets, as well as publically broadcasting market prices and new developments in farming techniques and quality standards.

VASEP also sponsors the An Giang Fisheries Association (AFA), a member-based organisation set up after the US Anti dumping case in 2003 to advocate farmers' interests in policy and negotiate individual contracts with processing companies. However, the survey found that only half of the respondents believed AFA operated effectively, providing information on inputs and market prices, production techniques and effective 
disease control. The remaining respondents thought AFA was ineffective because the association had no decisive role in negotiating contracts between members and processing companies, banks or feed companies. One in ten respondents said the relationship of AFA with processing companies was ambiguous and, as a result, members doubt its willingness to advocate their interests.

The main source of technical support for farmers is the Fishery Extension officers within the District Agriculture Departments. They offer training to hatchery and grow-out farmers in new aquaculture technologies as well as instruct farmers on governmental policies to increase Pangasius hygiene and safety. In addition, there are a range of technical programmes for farms including irrigation projects for raising aqua products, projects to upgrade breeding centres. More specialised support on veterinary issues is provided by the National Fisheries Quality Assurance and Veterinary Directorate (NAFIQUAVED), which is also responsible for checking, controlling as well as certifying feed, fingerlings and fish processing.

\subsection{Added value}

The average total net added value in the Pangasius chain is estimated at US $\$ 0.29$ per $\mathrm{kg}$. The results also show that the percentage net added value between actors in the export and domestic channels are relatively similar (Table 1). Traders contribute the lowest net added value at $17.5 \%$. Producers and retailers/processors in both import and export channels have a similar contribution of net added value; 41.3 and $40.1 \%$ in the export channel and 46.9$53.1 \%$ in the domestic channel. Overall, farmers' profit is similar in both of the channels at US $\$ 0.12$ per $\mathrm{kg}$. However, the share of profit and income differs greatly by size of farm. Table 2 shows that farms with a pond area of less than 0.5 ha make up $89 \%$ of all farms, but receive $11 \%$ of the income and only $4.8 \%$ of the profit from the export value chains.

The contribution of labour relative to benefits received differs between the chain actors. The results show that farmers contribute $1.2 \%$ of labour to the value chain and $38.7 \%$ of the net added value, while receiving $48.2 \%$ of gross profit and $44.5 \%$ of gross income from the chain. By comparison, traders contribute $3.4 \%$ of labour to the value chain and $17.5 \%$

Table 1 Integrated analysis of value in the Pangasius hypopthalmus chain in Vietnam

\begin{tabular}{|c|c|c|c|c|}
\hline $\begin{array}{l}\text { Actor } \\
\text { Analysis }\end{array}$ & Farmers & Traders & Processors & Total \\
\hline 1. Total working time (months) & 107 & 81 & 20680 & 20868 \\
\hline 2. Total labour cost (US\$) & 10048,68 & 6526,07 & 2873124,80 & 2889699,60 \\
\hline 3. Volume traded (tonnes) & $1,200,000$ & 106,800 & $1,096,800$ & \\
\hline 4. Selling price (US\$/kg) & 0.92 & 1.06 & 1.15 & \\
\hline 5. Profit (US\$/kg) & 0.12 & 0.05 & 0.14 & \\
\hline 6. Gross profit (million US\$) & 144.00 & 5.34 & 153.55 & 302.89 \\
\hline 7. Gross income (million US\$) & 1104.00 & 113.21 & 1261.32 & 2478.53 \\
\hline 8. Labour costs (US\$/kg) & 0.0002 & 0.0007 & 0.0196 & \\
\hline 9. Percentage share of labour costs per $\mathrm{kg}$ & 1.2 & 3.4 & 95.4 & 100.0 \\
\hline 10. Percentage share of profit per $\mathrm{kg}$ & 38.7 & 17.5 & 43.8 & 100.0 \\
\hline 11. Percentage share of total profit & 48.2 & 1.9 & 49.9 & 100.0 \\
\hline 12. Percentage share of total income & 44.5 & 4.6 & 50.9 & 100.0 \\
\hline
\end{tabular}


Table 2 Income and profit of grow-out farms selling to the export value chain by size of farm

\begin{tabular}{|c|c|c|c|c|c|c|}
\hline \multirow[t]{2}{*}{ Size of farm } & \multicolumn{2}{|c|}{$\begin{array}{l}\text { Proportion } \\
\text { of farms }\end{array}$} & \multicolumn{2}{|c|}{$\begin{array}{l}\text { Direct sale to processing } \\
\text { companies }\end{array}$} & \multirow[t]{2}{*}{$\begin{array}{l}\text { Share of farmer } \\
\text { profit }(\%)\end{array}$} & \multirow[t]{2}{*}{$\begin{array}{l}\text { Share of farmer } \\
\text { income }(\%)\end{array}$} \\
\hline & Survey & All* & $\begin{array}{l}\text { Percentage } \\
\text { of farms }\end{array}$ & $\begin{array}{l}\text { Percentage } \\
\text { of volume }\end{array}$ & & \\
\hline$<0.5$ ha & 49 & 89 & 84 & 10.3 & 4.8 & 11.0 \\
\hline $0.5-1$ ha & 24 & 6 & 100 & 19.4 & 27.4 & 19.3 \\
\hline$>1$ ha & 27 & 5 & 100 & 61.4 & 67.8 & 64.1 \\
\hline Total & 100 & 100 & & 91.1 & 100 & 100 \\
\hline
\end{tabular}

* Based on DARD and DoS (2008) census of ponds-see Table 6

of net added value, while receiving $1.9 \%$ of gross profit and $4.6 \%$ of the gross added value in the chain. The rest of the labour is contributed by processing companies. In return, processing companies receive $49.9 \%$ of the gross profit which is similar to the overall share of farmers but 26 times higher than the share of traders. By comparison, we estimate the average gross profit of a single processing company at US $\$ 1,861,642$ per year and the average gross profit for individual farmers at US\$11,621 per year.

The unequal proportion in profit and income among the actors in the value chain highlights a significant vulnerability. Consequently, there is an endemic cycle of over and under supply within the chain that affects the confidence of farmers and processing companies alike to invest in improving infrastructure and supply contracts.

Further data collected in August 2008 illustrate this cycle, with farmers costs having risen sharply, largely due to peak fuel prices in 2008. The cost of feed in particular rose between US\$0.06 and US\$0.09 per kg to a current average price of between US\$0.48 and US\$0.54 per $\mathrm{kg}$. At the same time, declining demand in international markets led to decrease in market price to US $\$ 0.88$ to US $\$ 0.92$, approximately US $\$ 0.10$ to US $\$ 0.13$ per $\mathrm{kg}$ lower than the total cost per $\mathrm{kg}$. In addition, it appears the price of antibiotics and vitamins has increased between 30 and $40 \%$ compared to 2007. Based on these figures, it is estimated the market price for Pangasius needs to rise to US\$0.98 per $\mathrm{kg}$ to ensure profitability.

\section{Henicorhynchus/Labiobarbus spp. value chain}

\subsection{Value chain actors, functions and channels}

The survey recorded 79,800 tonnes of Henicorhynchus/Labiobarbus spp. traded in 2007 through a value chain consisting of five main actors, operating in three channels (Fig. 3). Because of the lack of information on total catches, it is not possible to estimate what proportion of the total capture production this represents. The first value chain channel passes from fishers to traders and processors before being sold to either domestic or international markets. This channel comprises $11.9 \%$ of the total volume traded, with $3.1 \%$ passing directly through to export markets and $8.7 \%$ passing back to retailers before being sold to domestic markets. A second channel, making up $8.1 \%$ of total volume, passes from fishers to traders before being sold directly to domestic markets. This channel passes from fishers to retailers and onto domestic markets making up $18.7 \%$ of total fish traded. Finally, fish are traded through a direct channel from fishers to domestic consumers. In most cases, 


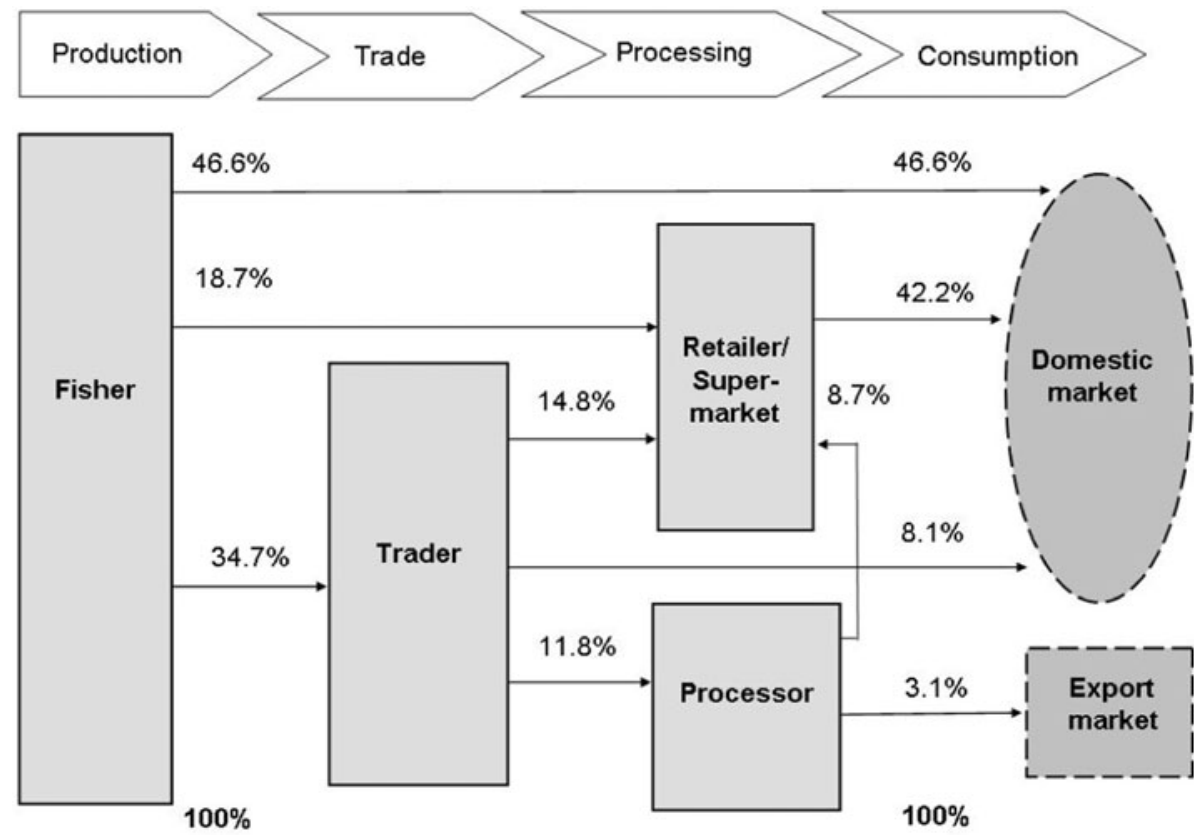

Fig. 3 Henicorhynchus/Labiobarbus spp. value chain Vietnam

this exchange occurs locally between households and comprises the majority of the Henicorhynchus/Labiobarbus spp. traded.

There is no reliable data on the quantities of Henicorhynchus/Labiobarbus spp. exported. However, two companies have also begun selling the fish to international markets in cans. The Antesco Company sells canned fish with sugarcane and exports $10 \%$ of its 15 tonnes/year production, and the Ba Giao Khoe 55555 Salted Fish Company exports $60 \%$ of its 150 tonnes/year production of salted and dried fish. Both companies report that their fish is imported from Cambodia. This fish bypasses the main trade networks, and therefore not detected in the survey, because the companies hire boats that travel directly to the Dai fishery on Tonle Sap during the main fishing season.

\subsection{Supporters and facilitators}

There are no formal organisations or institutions supporting actors in the Henicorhynchus/ Labiobarbus spp. value chain. The actors in the chain make decisions related to production and trade based on their own experience with the largely migratory fishery during the wet season.

Fishers rely heavily on informal support services for credit and technical information. The results show that $34 \%$ of respondents receive informal loans for replacing fishing equipment, boat maintenance and fuel. A quarter of these respondents borrowed from private lenders with an average interest rate of $10 \%$ per month. By comparison family lending networks charge an average interest rate of $9 \%$ per month over 18 months, while the women's union charge a much lower interest rate of $0.7 \%$ per month over 12 months. Respondents also report receiving informal support from traders with preservation technologies, including ice and cool boxes. In return, these traders buy all of their fish and do 
not permit the fishers to sell to their competitors-a practice common across the Mekong Basin (e.g. Bush and Le Minh 2006; Bush 2004; Navy 2004; Seng 2006).

Vietnamese fishers report not being able to readily access formal credit because of a lack of collateral. As such, these fishers see informal 'quasi-credit' arrangements (see Platteau and Abraham 1987) as preferable because they provide flexible credit which allows them to repackage their debt by balancing repayments with fish or cash, therefore, ensuring they can meet their family's subsistence needs before selling their surplus. In addition, debt-tied trade is independent of market price fluctuation. As interest rates are embedded in the price fishers are not affected by these changes. In contrast, fishers reported that formal lending is inflexible, with repayment schedules that do not allow for seasonal variation in catch.

\subsection{Added value}

The average total net added value in the Henicorhynchus/Labiobarbus spp. chain is estimated at US $\$ 0.68$ per $\mathrm{kg}$ (see Table 3). The analysis shows that while fishers contribute $82.4 \%$ of total labour cost to the value chain, they only contribute $20.4 \%$ of net added value and receive $40.7 \%$ of the total profit and $41.2 \%$ of the total income. By comparison, collectors contribute $6.4 \%$ of total labour costs and receive $4.3 \%$ of the profit per $\mathrm{kg}, 2.1 \%$ of the total chain profit, and $12.3 \%$ of total income of the whole chain. Retailers contribute $11.2 \%$ of total labour cost and receive $75.3 \%$ profit: 3.7 times more than fishers and 17.5 times more than collectors and wholesalers. Retailers also capture half of the total profit of the chain and $46.5 \%$ of the chain's total income.

The relative geographical isolation of many of these fishers, their low levels of operating capital, and poor access to formal credit means they are dependent on collectors and retailers. Unlike the Pangasius chain, it appears fishers are more dependent on retailers to sell Henicorhynchus/Labiobarbus spp. to domestic retail markets. For large-scale fishers, this is due to the high volume of fish caught in migratory seasons, requiring fast, efficient and specialised market provisioning. In comparison, small-scale fishers are more

Table 3 Integrated analysis of value in the Henicorhynchus/Labiobarbus spp. chain in Vietnam

\begin{tabular}{lllll}
\hline $\begin{array}{l}\text { Actor } \\
\text { Analysis }\end{array}$ & Fishers & $\begin{array}{l}\text { Collectors/ } \\
\text { wholesalers }\end{array}$ & Retailers & Total \\
\hline 1. Total working time (months/year) & 30 & 26 & 10 & 66 \\
2. Total labour cost (US\$) & 1913.40 & 937.57 & 637.80 & 3488.77 \\
3. Trading volume (tonnes) & 79,800 & 19,551 & 30,883 & 0.96 \\
4. Selling price (US\$/kg) & 0.33 & 0.40 & 0.51 & 0.68 \\
5. Profit (US\$/kg) & 0.14 & 0.03 & $15,750.3$ & $27,508.8$ \\
6. Total profit (1000 US\$) & $11,172.0$ & 586.5 & $29,647.7$ & $63,802.1$ \\
7. Total income (1000 US\$) & $26,334.0$ & $7,820.4$ & 0.00 & 0.01 \\
8. Labour costs (US\$/kg) & 0.01 & 0.00 & 11.2 & 100.0 \\
9. Percentage share of labour costs per kg & 82.4 & 6.4 & 75.3 & 100.0 \\
10. Percentage share of profit per kg & 20.4 & 4.3 & 57.2 & 100.0 \\
11. Percentage share of total profit & 40.7 & 2.1 & 46.5 & 100.0 \\
12. Percentage share of total income & 41.2 & 12.3 & & \\
\hline
\end{tabular}


dependent on retailers and collectors to purchase their fish at landing sites because of the poor economy of scale they face in transporting small, inconsistent quantities to market.

\section{Value chain-dependent livelihoods}

Livelihoods analysis adds to the results of the structure and function of the two value chains by comparing the vulnerability of fishers and farmers to economic and political change. The following addresses the economic vulnerability of fishers and farmers, by presenting results from the survey on: (1) the challenges fishers and farmers face in securing their livelihoods within global and regional value chains, (2) the awareness of farmers and fishers of prevailing government policy and regulation and (3) the impact these policies have on farmer's ability to secure their livelihoods.

\subsection{Pangasius farmers}

Pangasius farmers have an investment ratio of 1.04. This is comparable to the findings of Ngo (2008) and Sinh and Hien (2009) showing rates of return for grow-out farmers of 1.13 and 1.12 , respectively, with a standard deviation of 1.17. Although returns are positive, they are associated with a high degree of variation and, therefore, risk. The risk inherent in the industry is also indicated by the increasing failure rates of farmers in the Delta (Fig. 4). It is possible that the estimated 30\% of farmers that have remained profitable in 2009 are the larger industrial farmers who account for between $91.4 \%$ of the total export production.

The results show that the average production costs of Pangasius grow-out farmers are US $\$ 462,729$ per hectare per year or US $\$ 240,649$ per hectare per crop (Tables 4,5 ). However, the later figure differs considerably by size of farm, with larger farms being considerably more efficient than smaller farms in their production costs. Overall, Pangasius grow-out farmers make a return on investment of $4.2 \%$, higher than many other industries, with medium and larger farmers receiving returns of up to $16.2 \%$. However, these returns are offset by the largest number of smaller farmers that in recent years have had a negative return. In addition, the wider trend in the industry of farmers leaving aquaculture

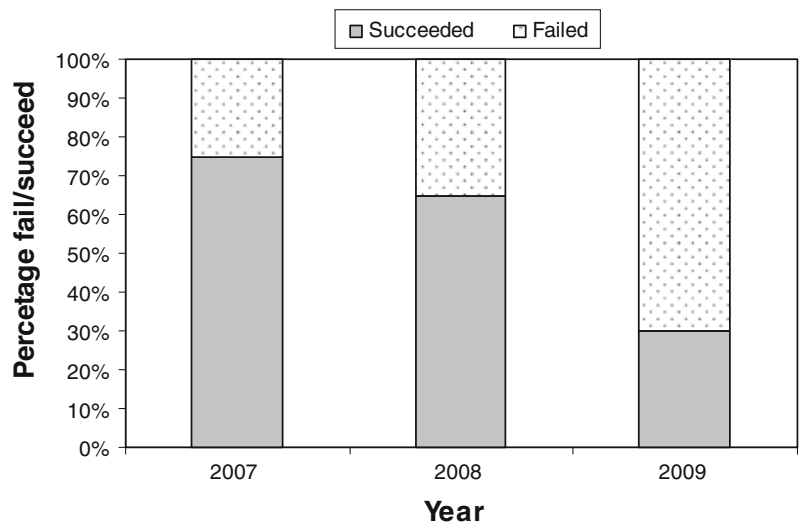

Fig. 4 Success and failure rate of Pangasius producers 2007-2009. Based on data from Sinh and Hien (2009), Ngo (2008) and government estimates made at the Pangasius Aquaculture Dialogue July 2009, Can Tho University 
Table 4 Contribution of the activities to total annual costs and total annual net income

\begin{tabular}{|c|c|c|c|c|c|}
\hline Description & $\begin{array}{l}\mathrm{H} / \mathrm{L} \text { spp. } \\
\text { fishers* }\end{array}$ & $\begin{array}{l}\mathrm{H} / \mathrm{L} \text { spp. } \\
\text { traders* }\end{array}$ & $\begin{array}{l}\text { Pangasius } \\
\text { hatcheries }\end{array}$ & $\begin{array}{l}\text { Pangasius } \\
\text { nurseries }\end{array}$ & $\begin{array}{l}\text { Pangasius } \\
\text { grow-out farmers }\end{array}$ \\
\hline Total costs/year (US\$) & 53 & 10 & 28 & 53 & 62 \\
\hline Mean & 4649,56 & 10396,14 & 250649,02 & 178717,94 & 462768,55 \\
\hline Std deviation & 10593,86 & 9707,32 & 597108,36 & 477648,42 & 593893,85 \\
\hline \multicolumn{6}{|c|}{ Total net income/year (US\$) } \\
\hline+ Mean & 1581,74 & 1575,37 & 27380,75 & 21072,91 & 10208,05 \\
\hline+ Std deviation & 2085,61 & 637,80 & 28956,12 & 30384,79 & 42337,16 \\
\hline \multicolumn{6}{|c|}{ Net income per capita/year (US\$) } \\
\hline Mean & 344,41 & 408,19 & 6416,27 & 4783,50 & 2676,70 \\
\hline Std deviation & 497,48 & 197,72 & 7462,26 & 7034,93 & 10561,97 \\
\hline
\end{tabular}

* Henicorhynchus/Labiobarbus spp

Table 5 Return of Investment of grow-out farmers by size of farm

\begin{tabular}{lllccr}
\hline Size of farm & $\begin{array}{l}\text { Production cost } \\
\text { (US\$/ha) }\end{array}$ & $\begin{array}{l}\text { Turnover } \\
\text { (US\$/ha) }\end{array}$ & Profit (US\$/ha) & $\begin{array}{l}\text { Investment } \\
\text { ratio }\end{array}$ & ROI (\%) \\
\hline$<0.5$ ha & 263516,18 & 246791,74 & $-16724,45$ & 0,94 & $-6,3$ \\
$0.5-1$ ha & 274838,95 & 319462,56 & 44623,61 & 1,16 & 16,2 \\
$>1$ ha & 167382,46 & 195419,63 & 28037,17 & 1,17 & 16,8 \\
Total & 240648,59 & 250856,64 & 10208,05 & 1,04 & 4,2 \\
\hline
\end{tabular}

* Based on DARD and DoS (2008) census of ponds-see Table 6

Table 6 Changes in the number of Pangasius farms in An Giang Province by area of ponds

\begin{tabular}{|c|c|c|c|c|c|c|c|c|c|}
\hline \multirow{2}{*}{$\begin{array}{l}\text { Area of ponds } \\
\left(\mathrm{m}^{2}\right)\end{array}$} & \multicolumn{3}{|c|}{ Number of farms } & \multicolumn{3}{|c|}{ Proportion (\%) } & \multicolumn{3}{|c|}{ Percentage change } \\
\hline & 2006 & 2007 & 2008 & 2006 & 2007 & 2008 & 2006-2007 & 2007-2008 & 2006-2008 \\
\hline$<500$ & 1,910 & 1,271 & 913 & 38,4 & 16,8 & 16,7 & -33 & -28 & -52 \\
\hline $500-1,000$ & 1,040 & 1,884 & 945 & 20,9 & 24,9 & 17,3 & 81 & -50 & -9 \\
\hline $1,000-2,000$ & 1,064 & 1,778 & 1,530 & 21,4 & 23,5 & 28.00 & 67 & -14 & 44 \\
\hline $2,000-3,000$ & 358 & 1,339 & 945 & 7,2 & 17,7 & 17,3 & 274 & -29 & 164 \\
\hline $3,000-5,000$ & 313 & 620 & 530 & 6,3 & 8,2 & 9,7 & 98 & -15 & 69 \\
\hline $5,000-10,000$ & 159 & 401 & 317 & 3,2 & 5,3 & 5,8 & 152 & -21 & 99 \\
\hline $10,000-20,000$ & 95 & 159 & 175 & 1,9 & 2,1 & 3,2 & 67 & 10 & 84 \\
\hline$>20,000$ & 30 & 106 & 104 & 0,6 & 1,4 & 1,9 & 253 & -2 & 247 \\
\hline Total & 4,969 & 7,558 & 5,459 & 100 & 100 & 100 & 52 & -28 & 10 \\
\hline
\end{tabular}

Adapted from DARD and DoS (2008)

production in recent years also demonstrates the high risk nature of grow-out production (see Table 6).

Nursery farmers and hatcheries also have considerable costs, but only 39 and 54\% of the costs incurred by grow-out farmers. Nursery farmers are also the most profitable with a 
return on investment of $\sim 11 \%$, reflecting the higher risk of mortality in this phase of production. Despite this risk, nurseries succeed with $77.9 \%$ of their crops, $3 \%$ more than grow-out farmers. The failure rate is only $3 \%$ higher than that of grow-out farmers; however, the impact of a crop failure is considerably more catastrophic for a grow-out operation because of the much higher cost of production. For example, if processing companies refuse to buy the fish or disease kills the fish in the last month of production, it can take up to 3 years before they return to consistent profit margins.

Pangasius hypophthalmus aquaculture is a relatively new activity with $55 \%$ of the households investing in production after 2003. The large investment farmers make in Pangasius means they are less willing to diversify away from Pangasius, (Fig. 5). This is either because of the high returns they receive when production succeeds, or because they need to persist with production to pay off debts. The survey found that grow-out farmers are two times less likely to be involved in trading activities than hatchery and nursing households. However, as production has remaining profitable has become more difficult, many farmers have diversified away from production. Information from DARD and DoS (2008) indicates that the number of small and medium farmers producing Pangasius fluctuated greatly between 2006 and 2008 (see Table 6). In particular, farmers with a pond area less than 0.1 ha have decreased $52 \%$, shifting their production to alternative species such as Channa spp. (Snakehead), Trichogaster pectoralis (Snakeskin Gourami) and Tilapia spp.

\subsection{Fishing households}

Fishing households have average annual costs of US\$4649.56-84\% less than Pangasius grow-out farmers (Table 4). Fishers and fish traders have the highest return on investment of all groups surveyed at 34 and $15 \%$, respectively. However, in real terms, fishing households receive a total net income of US\$1581.74, or US\$344 per person per year, approximately ten times less than Pangasius farmers. As shown in the value chain analysis, the main constraint this group faces in increasing their income is their lack of ability to negotiate prices as a result of the quasi-credit contracts they have with traders. The results also show that landless fishing households without alternative income streams from agriculture have a per capita income approximately US\$200 per year higher than what the

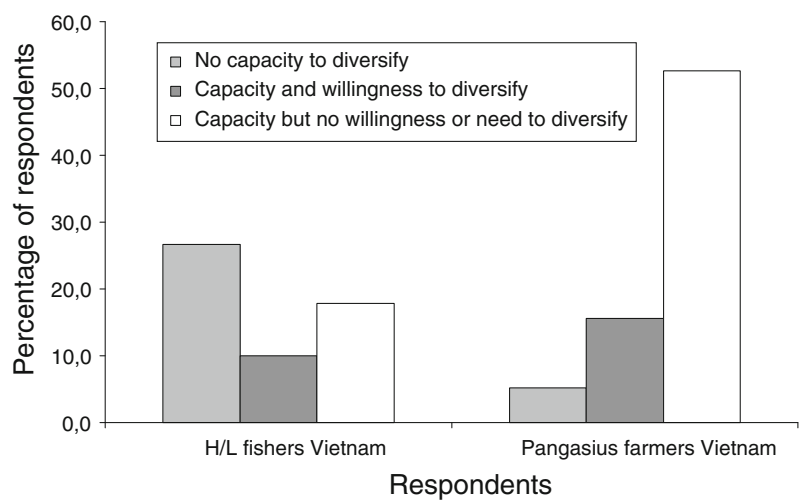

Fig. 5 Capacity and willingness of farmers to diversify their primary livelihood activity away from fishing or farming 
government classifies as 'poor' (MOLISA 2005). Furthermore, only 59.9\% of Henicorhynchus/Labiobarbus spp. fishers and $61 \%$ of Henicorhynchus/Labiobarbus spp. traders reported marking a profit during the past 5 years, again indicating the variability of catches and increasing price of inputs such as fuel.

Fishing is a secondary occupation to agriculture and livestock, but remains an important source of income with only 30 and $37 \%$ of households carrying out rice farming or livestock, respectively. As indicated in Fig. 4, fishers are more willing to diversify than Pangasius farmers. However, very few fishing households have the capacity to diversify, especially in Pangasius aquaculture. As indicated by the DARD and DoS (2008) census data, Pangasius appears to be an increasingly unlikely option for rural households in the Mekong Delta given the $37 \%$ decline in the smallest category of Pangasius farms between 2006 and 2008 (see Table 6). Our results show that since 2003, only 4\% of fishing household respondents have invested in Pangasius farming, while the number of households dependent solely on fishing for their income has increased $13.2 \%$. This further demonstrates the difficulties fishers face in investing in the industry and the consolidation of Pangasius in the hands of larger, capital intensive investors.

\subsection{Challenges to livelihoods}

Fishers and farmers face a series of challenges in securing their livelihoods in the face of changing market relations. The results indicate that the key challenges for both groups are their limited capacity to negotiate the terms of employment and access to credit.

Off-season labour for fishers on Pangasius farms is increasingly difficult to find because of the technical skills needed to effectively manage feed, stocking and the use of chemicals. An increasing proportion of farm employees are university educated making it difficult for farmers, who on average have a primary school education, to compete. Unskilled labour is used predominantly for seasonal pond harvesting, which pays on average US\$230 per month; only marginally above the threshold for 'poor' households, and too low, they report, to support their families. Conversely, farmers are concerned about the increasing expectations labourers have for their rates of pay, arguing that that they are already being squeezed from higher costs of production. The need to employ skilled labour for technical aspects of production also means that costs have increased because of the risk of chemical contamination. The result is greater competition for university graduates, which has subsequently driven up average wages from US\$88 per month in 2006 to US\$103 per month to 2008 .

Both fishers and farmers rely heavily on credit from family networks and middlemen. Although these informal sources credit provide an important source of short-term finance, it also limits their ability to adapt to rapidly changing production costs and market prices. Middlemen in particular are an important source of financial support for $7.8 \%$ of farmers and $30.8 \%$ of fishers who are unable to get formal loans. Nearly two-thirds of respondents reported being reliant on these family networks for financial and technical support when they had low production or when cash was needed for household emergencies. The results show the flexibility on loan repayments and the additional support they often receive when emergency credit is needed outweighs the benefits of having a lower interest rate with formal credit. Nevertheless, approximately half of all respondents said they would like to bypass their trader-creditors by establishing more direct trading relations with processing companies and retailers. 


\subsection{Policy awareness and support}

Approximately half of the Pangasius farmers surveyed were concerned about the emergence of environmental regulations over production. However, only $37 \%$ of fishers thought that any real impact would eventuate from these regulations because of the low level of surveillance over their activities by government officials. The main areas of concern for farmers and fishers alike include land and water policy, technical support for pond design and access to credit. In addition, fishers are concerned about the impact of fishing regulation on their activities.

Approximately three-quarters of farmers were able to recognise the key government regulations related to land and water management, but all reported that these had little or no impact on their production practices. Despite wanting to move their ponds to more suitable land, or extend their system to include sediment ponds, smaller farmers are constrained by the cost of renting of buying new land. Larger, wealthier farmers are more able to comply with site selection criteria and water treatment regulations when expanding their operations. However, low enforcement by government agencies has meant that many of these producers have been able to avoid having to comply with these regulations.

Farmers are particularly knowledgeable about chemical use; however, only $25 \%$ of all respondents believe these regulations have any benefit to production. There are two main reasons farmers choose not to comply with these regulations. First, they wish to protect their investment from disease as well as wanting maximum growth in shortest length of time. Second, farmers believe they are able to apply many of the chemicals and then, by stopping the application of these chemicals in time, avoid detection by the processing companies.

Policies relating to seed are seen by farmers as being moderately successful. More than $80 \%$ of farmers are aware of the government's attempts to centralise control of seed quality through State-operated 'seed centres', but only half of these farmers see the policies as providing more security to their production. Consequently, half of the farmers surveyed believe that the policies make no perceivable difference to their production. Similarly, policies relating to the use of manufactured feed and the registration of farms are seen as having the most positive effect. Fewer farmers knew about these policies than knew of policies related to seed and drug use regulation. Furthermore, two-thirds of respondents believed policies related to seed had no positive impact on their production because they rely mainly on their own experience, or advice from other famers and suppliers.

As farmers are embedded in increasingly global value chains, they are being exposed to formal contractual arrangements. Farmers throughout the Delta in particular argue that more elaborate contractualisation to processing companies signed at the start of a production cycle would decrease their vulnerability to price fluctuation. Despite these observed benefits, less than half of the respondents knew of government policies designed to promote better conditions for production contracts. Nearly three-quarters of those who knew about the policies believed they had no impact on their production and trading activities. The main reason for this negative assessment is that parties breaking contracts are rarely prosecuted.

Vietnam has developed laws related to the marketing of fish products, including registration of traders and monitoring of quality management in wholesalers and processing companies. Despite the effort to promote these laws as part of the wider push for an exportdriven economy, only $58 \%$ of respondents know of these policies and regulations. Furthermore, approximately two-thirds of respondents reported that these marketing policies have little impact on their production and trading practices. 
Fishers were relatively knowledgeable about policies and regulation related to fishing and the use of water resources. In total, 88 and $62 \%$ of fishers knew about recent changes to these respective policies. However, nearly $90 \%$ of fishers acknowledge that these policies have little or no effect on environmental protection. Fishing regulations were acknowledged as having brought about change in fishing practices by only $12.5 \%$ of respondents, while $44 \%$ argued that these regulations had no effect on fishing, largely because of "free riding" behaviour and poor enforcement of the use of illegal fishing gear.

\section{Discussion}

\subsection{Value chain form and function}

The results confirm the export orientation of the Pangasius industry and show a new trend to export markets for Henicorhynchus/Labiobarbus spp. in Vietnam. New markets for Henicorhynchus/Labiobarbus spp. hold significant implications for fishers as the overall catch of the fish declines and prices increase. The more transparent and vertically integrated export oriented chains show the potential for small-scale farmers to capture significantly higher value than fishers. However, the results demonstrate that fishers and growout farmers are the most vulnerable actors in their respective chains. The main constraint faced by fishers and farmers is their poor bargaining power. Both groups account for the lowest gross added value and receive the lowest income of any actor in their respective value chains. In contrast, processors and retailers capture more than two-thirds of the gross profit in the chain.

The results also show there is relatively little support for Henicorhynchus/Labiobarbus spp. fishers. Until now, there have been few state, private or NGOs who have intervened in the value chains to provide technical support or regulation over quality or safety. The fishery remains largely outside the government's regulation and control, especially as a large proportion of the fish is thought to come across the border from Cambodia. There are very little data on this transboundary trade, but there is some evidence that the volume of trade is considerable. For example, Seng (2006) estimates that in 2003 traders were selling a large amount of small species such as Henicorhynchus/Labiobarbus spp. for US\$0.34 per $\mathrm{kg}$. As demand for the fish increases in Vietnam, especially in domestic and export consumer markets, these illegal flows of fish may become more important.

For fishers to capture a higher share of profits, they will have to strengthen their links with retailers and bypass collectors and wholesalers. However, there are considerable constraints to achieving structural change in these value chains. The quasi-credit schemes restrict bargaining power of fishers, but they also enable access to credit that is largely unattainable for poor landless households. Even in the capital intensive Pangasius industry, quasi-credit schemes cover short-term cash flow issues for inputs such as feed and seed. Formal (micro) credit schemes may improve the transparency of the value chains and improve bargaining power, leading to a higher share of profit.

\subsection{Income and bargaining power}

The study estimates that the annual income of Pangasius farmers is five times higher than the regional average of US\$538 and 14 times higher than the annual income of fishers (CSO 2007). Although these farmers cannot be considered poor, their relatively high degree of specialisation and investment make them highly vulnerable to market fluctuation. 
As demonstrated by the international economic crisis of 2008 and 2009, it is increasingly difficult for farmers to continue to secure these income levels. The capacity of farmers to specialise or diversify appears to be important determinants of livelihood security.

Smaller Pangasius farmers appear to have less potential for growth given their limited land holdings, but they are more able to diversity to other fish species, or alternatively to downgrade from grow-out farming to nursing. (By comparison fishers appear willing to diversify their income streams away from fishing, but are unable to do so because of a lack of adequate capital.) If farmers diversify they do so vertically within the industry, shifting their operations to nursing or hatching during periods when inputs for grow-out farming are too high. Overall, farmers have been able to move between these three activities relatively successfully, mainly because the return on investment is also very high, if not higher than grow-out farming.

Pangasius grow-out farmers are highly dependent on the cost of feed which makes up nearly $90 \%$ of their total operating costs. Because their return on investment is only $4.2 \%$, the lowest of all the groups surveyed, any change in either the price of feed or lower market prices can lead to severe losses which are difficult to make up. One of the key mechanisms farmers use to cope with poor production or poor market prices is access to informal credit. However, farmers are more able to access credit through informal lenders meaning that any bridging finance comes with high interest rates and, if from their suppliers or traders, often implicit conditions of indebtedness. Given the variability of input prices and market demand is more likely to increase in response to the global economic downturn farmers will be faced with periods of greater economic vulnerability.

There is a distinct difference in the sources of vulnerability and the capacity of farmers and fishers to cope with external impacts. Farmers may be more able to deal with environmental impacts, especially as these appear to be relatively benign (see Bosma et al. 2009), but as farmers become more dependent on global value chains, they become exposed to new conditions of market entry and price fluctuation. Fishers are less exposed to these market fluctuations because traders take more risk in transporting the fish to market. The lower bargaining power may in fact insulate fishers from economic vulnerability; however, it also means that they are also unable to diversify away from fishing. Fishers also appear to be far more vulnerable to environmental change given their dependency on water quality for the health of fish stocks. They are becoming more vulnerable because they are dependent on fish stocks which appear to be in decline, or fully exploited. Unlike Pangasius farmers, these fishers do not have as much collateral for loans, or capital to diversify. Those that attempt to shift to aquaculture are more often than not unsuccessful.

\subsection{Extending value chain governance}

The results indicate that government intervention has not been effective in mitigating the impacts of environmental change, promoting alternative production technologies or reducing the exposure of fishers and farmers to market fluctuations. The success of the Pangasius industry has meant that policy, regulation, extension and enforcement have not been able to keep up with the innovation of farmers. The government has taken an essentially laissez-faire approach to the development of the Pangasius industry, largely due to the lack of evidence that there are serious environmental concerns related to production, and the support this growth has given to economic reform at the national level. Fishers also regard policies as largely ineffective due to the lack of capacity of the government to monitor fishing activities, and cross-border trade. 
For value chain governance initiatives to support sustainable production, they will have to overcome the limitations faced by state policy. The Vietnamese government has begun investing in the promotion of certification systems such as the WWF Pangasius Aquaculture Dialogue, GLOBALGAP and Safe Quality Foods (SQF) (see Bush et al. 2009). Questions remain over the division of responsibilities between these governance systems and the state: Can they provide extension and information? Can they provide technical support to farmers? Are they able to facilitate improved credit arrangements? Further research is needed, but it appears that private sector actors including processing companies, feed and chemical suppliers are key actors in extending information to farmers and are also better situated to respond to the needs of farmers than government extension services. Although up until now, few price premiums are available in return for compliance with international standards (see for example Mantingh and Dung 2008), value chain governance mechanisms may still have the greatest leverage over farmers by regulating access to lucrative international markets.

The results of the value chain and livelihoods analyses indicate value chain governance arrangements hold very real implications for the structure and function of trade in the Mekong Delta. As more than $90 \%$ of the volume traded goes to export markets, famers are dependent on high market prices to remain profitable. Low compliance with standards regulating these lucrative export markets might mean more fish will be directed into unregulated domestic markets. Consequently, a shift to domestic markets with similar prices to export markets means that grow-out farmers may be able to cope with shifting between channels. However, the higher demand for a variety of alternative fish species in domestic markets may also be a driving factor for smaller farmers to diversify away from Pangasius. It is more likely that these farmers will be the $89 \%$ majority of 'smaller' farmers that contribute between 20 and $30 \%$ of the production and receive only $4.8 \%$ of the net profit (see Table 2). The other $11 \%$ of larger farmers are more likely to consolidate their position in export markets with their stronger connections to the processing companies. For small-scale farmers to remain competitive, they may require cooperative forms of production to improve their economy of scale in both production and the costs of compliance.

The rise of value chain standards and third-party certification systems will increase the need for improved enforcement of contracts, both in terms of providing protection for farmers who need assurance that investments made in complying with standards will make a return. If domestic markets absorb fish that does not comply with environmental or social certification, the government will also play a continued role in food quality and safety governance.

For Henicorhynchus/Labiobarbus spp. fishers, the lack of policy enforcement and policy means their activities will remain relatively unchanged. The difficulty in accessing flooded areas to monitor the fisheries contributes to the lack of information which can be used to developed suitable regulation. Furthermore, there are few laws which address cross-boundary nature of fish(er) migration and trade. The diffuse nature of the resource and these trade networks means that the state will have to find alternative ways of regulating the resources. The government has been successful in regulating the Dai fisheries in the past, especially when there was cross-border tensions in the ownership of these nets by Cambodians in Vietnam. The increased scarcity of Henicorhynchus/Labiobarbus spp. and the higher value of the fish in domestic urban and international markets, there will be more financial incentive to monitor and regulate the fishery. As the fishery is highly migratory, management efforts will remain transboundary. Value chain approaches do not appear to hold much potential for governing the management of Henicorhynchus/Labiobarbus spp. in domestic markets. However, if good cross-border management can be established, then 
opportunities may open to also establish better control over cross-border trade of Henicorhynchus and Labiobarbus spp.

\section{Conclusion}

This study has provided the first detailed account of the form and function of high and low value fish chains in the Mekong Delta, their contribution to the livelihoods of farmers and fishers, and the potential for state and private led value chain governance to steer towards more equitable and environmentally responsible production. In all regards, the two value chains focus on in this study, P. hypopthalmus and Henichrohynchus/Labiobarbus spp., differ markedly. The main finding of the research is that actors in high value export chains have a higher potential income, but face considerably higher economic vulnerability. Alternatively, fishers are severely constrained in their ability to negotiate higher prices for their fish, but appear to be less vulnerable to economic and environmental change due to the social relations of trade. As a result, value chain governance is more likely to be effective in high value export chains than domestic or regional value chains.

Government policy in Vietnam has been successful in promoting the growth of the fisheries sector, but policy has proven less effective in supporting equitable distribution of benefits along value chains, and reducing the vulnerability of fishers and farmers. The area farmers believe the government can make the most important intervention is regulating their contracts with processing companies, as well as feed and seed suppliers. Farmers note that increased certainty over their variable costs and revenue will allow them to invest in cleaner production technologies such as water treatment. Given that vertical contractualisation will shift financial risk to processing companies, it is still unclear what further investment they will make in strengthening provisioning arrangements with farmers.

Fishers largely operate outside government control both in terms of their fishing practices and economic activities. Fisher's knowledge about policies and regulations in most policy areas remains low and they are subject to limited monitoring and surveillance. As even fishers note, stricter regulation and enforcement would reduce the incidence of violations. Any government intervention in credit and lending may prove ineffective given the flexible nature of repayments in informal and quasi-credit arrangements. Future external interventions in the Henicorynchus/Labiobarbus spp. should aim to better integrate governance arrangements that can build upon existing informal value chain arrangements. If resistance to state sponsored cooperative structures can be overcome, there may also be scope in expanding the role of commune level or community arrangements to increase collective bargaining power in markets.

Further research is needed to elaborate the structure and function of value chains for fingerlings, fish feed and fresh fish for human consumption; the trade-offs between higher market access and human consumption; the specific importance of processed Henicorynchus and Labiobarbus spp. in domestic, regional and international markets; the specific support different chain actors need to comply with emerging environmental and social regulation and standards; and finally, what new role the state should adopt to better regulate production vis-à-vis the growing role of private sector led value chain governance.

Open Access This article is distributed under the terms of the Creative Commons Attribution Noncommercial License which permits any noncommercial use, distribution, and reproduction in any medium, provided the original author(s) and source are credited. 


\section{References}

Allison, E. H., \& Ellis, F. (2001). The livelihoods approach and management of small-scale fisheries. Marine Policy, 25, 377-388.

Bosma, R. H., Hanh, C. T. T. \& Potting, J. (2009). Environmental Impact Assessment of the Pangasius Sector in the Mekong Delta. Hanoi and Wageningen, Ministry of Agriculture, Nature and Food Quality, The Netherlands and Ministry of Agriculture and Rural Development, Vietnam.

Bush, S. R. (2004). Scales and sales: Changing social and spatial fish trading networks in the Siiphandone fishery, Lao PDR. Singapore Journal of Tropical Geography, 25(1), 32-50.

Bush, S. R., Khiem, N. T., \& Sinh, L. X. (2009). Governing Pangasius for sustainable rural livelihoods and environmental performance: A review. Aquaculture Economics and Management, 13(4), 271-293.

Bush, S. R., \& Le Minh, N. (2006). Livelihoods, markets and governance: Market access and value adding for small-scale fishers in the Lower Mekong Basin. Phnom Penh, Cambodia: Oxfam America.

CSO. (2007). The Mekong Delta yearbook 2007. Can Tho: Can Tho Statistics Office (CSO).

DARD \& DoS. (2008). Results of the An Giang province fisheries survey. Long Xuyen, Vietnam: An Giang Department of Agriculture and Rural Development and the An Giang Department of Statistics.

Dorward, A., Poole, N., Morrison, J., Kydd, J., \& Urey, I. (2003). Markets, institutions and technology: Missing links in livelihoods analysis. Development Policy Review, 21(3), 319-332.

Dung, N. H. (2008) Vietnam Pangasius and World Markets Paper presented at the International Workshop on Pangasius Catfish. Can Tho University, 5-6 December.

Ellis, F. (2000). Rural livelihoods and diversity in developing countries. Oxford: Oxford University Press.

GTZ. (2007). Valuelinks manual: The methodology of value chain promotion (1st ed.). Eschborn: German Technical Cooperation.

Humphrey, J., \& Schmitz, H. (2004). Governance in global value chains. In H. Schmitz (Ed.), Local enterprises in the global economy: Issues of governance and upgrading (pp. 95-109). Cheltenham: Edward Elgar.

Kaplinsky, R. (2000). Globalisation and unequalisation: What can be learned from value chain analysis? Journal of Development Studies, 37(2), 117-146.

Kaplinsky, R., \& Morris, M. (2000). A handbook for value chain research. Ottawa: IDRC.

Loc, V. T. T. (2006) Seafood supply chain quality management in the Mekong Delta, Vietnam. Groningen: CDS thesis No.17, University of Groningen.

Loc, V. T. T., Sinh, L. X., \& Bush, S. R. (2007). Trans-boundary challenges for fisheries policy in the Mekong Delta, Vietnam: Implications for economic growth and food security. In T. T. Be, B. T. Sinh, \& F. Miller (Eds.), Challenges to sustainable development in the Mekong Delta: A regional perspective on important policy issues and research needs (pp. 102-142). Stockholm: Swedish Environment Institute.

Mantingh, I., \& Dung, V. N. (2008). Pre-assessment of the Pangasius sector: Towards sustainability. The Hague: Dutch Ministry of Agriculture, Nature and Food Quality.

Mitchell, J. \& Shepherd, A. (2006) Productive strategies for poor rural households to participate successfully in global economic processes. London, ODI. See http://www.odi.org.uk/plag/resources/reports/ 06_idrc_finalreport.pdf.

MOLISA. (2005). Decision QD 170/2005-decision of the prime minister on national poverty line, July 2005. Hanoi: Ministry of Labour, Invalids and Social Affairs.

Navy, H. (2004). The role of formal and informal credit in the fish marketing chain, Cambodia. Phnom Penh: Cambodia Post Harvest Fisheries Livelihoods Project, Community Fisheries Development Office, Department of Fisheries.

Ngo, N. V. (2008) Analysis of the Pangasius catfish industry in Dong Thap province. MSc Thesis. College of Aquaculture \& Fisheries, Can Tho University, Can Tho Vietnam.

Platteau, J. P., \& Abraham, A. (1987). An inquiry into Quasi-credit contracts: The role of reciprocal credit and interlinked deals in small-scale fishing communities. The Journal of Development Studies, 23(4), 461-490.

Porter, M. E. (1998). On competition. Cambridge, MA: Harvard Business School Press.

Porter, M. E. (2000). Location, competition, and economic development: Local clusters in a global economy. Economic Development Quarterly, 14(1), 15-34.

Seng, K. (2006) Fish Export and the Livelihood of the Poor. Phnom Penh: Department of Fisheries, Ministry of Agriculture, Forestry and Fisheries. Working Paper 11.

Sinh, L. X. (2007). Issues related to sustainable farming of catfish (Pangasius spp.) in Vietnam. In P. Leung, C. Lee, \& P. J. O’Bryen (Eds.), Species and system selection for sustainable aquaculture (pp. 333346). Ames, Iowa: Blackwell Publishing. 
Sinh, L. X., Hien, L. L. (2009). Supply and use of the seed of Pangasius hypophthalmus in the Mekong Delta, Vietnam. Proceedings of the Asian Pangasius Catfish Symposium, Can Tho University, 5-7 Dec 2008.

Thoa, N. T. K. (2009). Fisheries development in the Mekong Delta in the period of 2000-2007. Can Tho: Mekong Development Institute Research Report. 